\title{
Impact of the National Horticulture Mission (NHM) scheme on horticulture development in Vijayapura district Karnataka
}

\author{
BHEEMANAGOUDA O. PATIL AND S.B. HOSAMANI
}

Received : 25.05.2017; Revised : 17.08.2017; Accepted :01.09.2017

\begin{abstract}
National Horticulture Mission (NHM) is a programme formulated for the overall development of Horticulture sector in the country. The Karnataka state has implemented the developmental activities under the mission in the 30 districts, covering 16 important horticultural crops and the scheme has been in function successfully from 2005-06 to till. Vijayapura district is purposively selected for the study in which NHM scheme is been functioning since from 2005-06 to till. With this background the present study was undertaken to analyze the impact of NHM on area, production and productivity of Horticultural crops in Vijayapura district. The study is completely based on secondary data source. During post NHM period the trend turned reverse in all the crop groups except pulse crops, which gained its positive growth (5.09\%) and instability reduced during same period. Production of horticultural crops showed decreasing trend at the rate of -9 per cent per year during pre-NHM period and it turned to significant increasing trend at the rate of 9.99 per cent per annum in post-NHM period and similar trend was seen in case of productivity between the pre and post NHM periods. The instability in production and productivity were significantly reduced from 31.58 per cent to 37.93 per cent and from 9.38 per cent to 2.75 per cent, respectively during pre-NHM and post-NHM periods. During post-NHM period highest growth in area and production was observed for fruits (about $13.2 \%$ and $15.9 \%$, respectively) followed by vegetables (about $7.3 \%$ and $4.5 \%$, respectively). The instability in area and production were also significantly reduced during the same period. In Vijayapura district, fruits and vegetables crops are getting popular among farmers with the Government support under the NHM. Still there is scope to increase the area, production and productivity in horticultural crops by covering more area under the NHM scheme.
\end{abstract}

KEY WORDS : NHM, Compound annual growth rates, Instability index, Pre and post NHM

How to cite this paper : Patil, Bheemanagouda O. and Hosamani, S.B. (2017). Impact of the National Horticulture Mission (NHM) scheme on horticulture development in Vijayapura district Karnataka. Internat. J. Com. \& Bus. Manage, 10(2) : 121-128, DOI: 10.15740/ HAS/IJCBM/10.2/121-128.

MEMBERS OF THE RESEARCH FORUM

Correspondence to:

BHEEMANAGOUDA O. PATIL, Department of Agricultural Economics, College of Agriculture, University of Agricultural Sciences, DHARWAD (KARNATAKA) INDIA

Email: bheemagriecon@gmail.com

\section{Authors' affiliations:}

S.B. HOSAMANI, Rani Channamma University, BELAGAVI (KARNATAKA) INDIA 